\title{
Asylum and Refugee Status in Portugal
}

\section{Lucio Sousa}

\begin{abstract}
Portugal does not have a tradition of receiving refugees. Similarly, the study of refugee issues is also very incipient. This short paper intends to be a small contribution to this field of research by presenting an analysis of the evolution of the Refugee Status in Portugal.
\end{abstract}

\section{Resume}

Le Portugal n'a pas de tradition d'accueil des refugies. Corrolairement I' etude des questions concernant Ie refuge y est plutot limitee. Ce bref article se veutune modeste contribution a ce champ de recherche par la presentation d'une analyse de l'evolution du statut de refugie au Portugal.

Portugal does not have a tradition of admission and reception oflarge fluxes ofrefugees. The exceptions could be the thousands that fled from the Civil War in Spain and the flux of some 200,000 who transited throughout the country to the Americas during the Second World War.

The April Revolution in 1974 brought changes in the political, socioeconomic and demographic characteristics of the country, namely the inflexion of the international migration patterns. Among these included the repatriation of some 800,000 Portuguese from ex colonies and the rising of the foreign population.

Lucio Sousa is an anthropologist finishing his Masters Degree in Intercultural Relations at the Open University in Portugal with a study on refugee integration in the Portuguese society.

\section{Fluxes and recognitions}

In this context, the figures of asylum seekers are rather low. Between 1974 and $1997^{1}$ the total applications were 12,782 including 9,665 individual applications and 3,117 family members. These figures are mostly concentrated in two periods around the years 1980 and 1993. Until the end of the eighties most of the asylum seekers came from the Portuguese speaking countries of Africa (P ALOP). This African pattern is a main characteristic of the asylum seekers in Portugal and a primary distinction when comparing with other Western European countries.

Only in the period around the year 1993 did the origin of asylum seekers get closer to the European pattern when the largest part of the asylum seekers came from Eastern Europe. Nowadays, the pattern of spontaneous asylum relays again in the African pattern now mainly from West African countries.

But the figures may present only part of the issue. In fact, sociologically, it is arguable that many of those arriving from Angola and Mozambique in the seventies and the eighties could be deemed as refugees ${ }^{2}$ - It is possible that this situation can still happen in this decade in the Angolan case ${ }^{3}$.

As for the status recognition, between 1974 and 1997,961 cases were granted (414 for family members ). After 1994, the residence permit for humanitarian reasons was given 103 times. Most of these recognitions were from Africa (86\%), and $75 \%$ from the PALOP. Nevertheless, it is important to mention that between 1974 and 1993 the Portuguese nationality was granted in 2394 cases before the first decision or after a negativeone. Of these, theP ALOP, especially between 1978 and 1984, account for 2359 (98.5\%).

\section{Refugee Status}

In order to analyse the evolution of Refugee Status in the Portuguese law we will use Zolberg's (1989) 4 categories of activist, target and victim for describing it.

Although Portugal had signed the 1951 Geneva Convention in 1960 only in 1975 was the New York Protocol signed. In the 1975 Constitution, the asylum was recognised to those who fought towards democracy, hence labelled as the activist.

Only in 1980 the first asylum law, $38 / 80$, was elaborated. This law recognised the refugee status under the Constitution, the 1951 Geneva Convention premises for humanitarian reasons for those coming from war torn countries. The activist, the target and the victim would receive the same level of protection.

This law lasted until 1993 when a new asylumlaw,70193, was created. It incorporated the latest developments in restrictions on asylum procedures arising from the Shengen and Dublin agreements. The changes meant that now only the activist and the target were deemed to receive the status of refugee. The humanitarian asylum was turned into a resident permit for humanitarian reasons for one year, renewable, giving less protection degree to the victim.

Recently the asylum law has changed. In 1998 a new asylum law, 15/98, considers basically the same refugee status for the activist and the target, yet, there is one improvement in the residence permit for humanitarian reasons, (no longer a discretionary measure but turned into a concession).

The novelty arises with the concept of temporary protection, portrayed as way of dealing with large groups. A striking aspect of this concept is that it can be applied both for the victim, the target or even the activist. For example, recently, the Guinea Bissau refugees that come to Portugal can be seen as victims. Mean- 
while, the Kosovar refugees can also receive this temporary protection. Despite being victims of war, they are clearly in a situation of target recognisable under the Geneva Convention because they fled due to their ethnic affiliation.

In conclusion, the official fluxes are very small and the main fluxes of such refugees originate from Africa and the PALOP. As for the refugee status we could say that the evolution, after a period marked by the decolonisation linkages and generous concept, has changed towards the European harmonising process, with a more restricted vision of the refugee status and the dazzling diversification of asylum processes.

\section{Notes}

1. Sources: Division of Refugees (Aliens and Borders Police); Costa, José Martins Barra da (1996), Exílio e Asilo (A questão Portuguesa 1974 - 1996), s. ed., Lisbon, Universidade Aberta.

2. Pires, R., Saint-Maurice, A. (1989), Descolonizações e Migrações, os imigrantes dos PALOP em Portugal, Revista Internacional de Estudos Africanos, $\mathrm{n}^{\circ} 10$ and 11, p.203-226.

3. Like recent news suggest, see Público 99/ $01 / 22$.

4. Zolberg, Aristide R.; Suhrke, Astri; Aguayo, Sergio, (1989), Escape From Violence Conflit and the Refugees Crisis in the Developing World, s. ed., New York, Oxford University Press. $\square$

( The author thanks Rosário Tique for comments on the draft.)

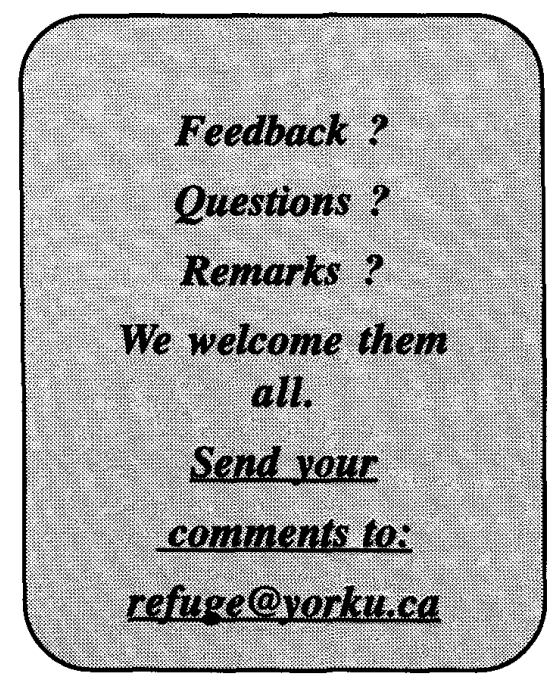

CRSTILP PUBLICATIONS BOOKS

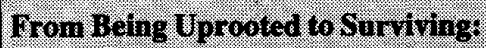
Resettlement of heVtethamiese.

Chinese 4 Bont Reople'? in

Montral, $1980-1900$

Lawrence Lam (1996)

1.10.95

Asylun- A Moral Milenan

W. Ounher Plaur (cospublished Win Praeger Pubushers) $(1985)$ 39.90

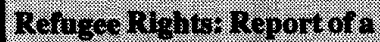

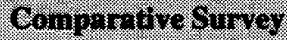

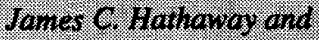

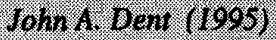

.01160

Legitimate and II Gitimate

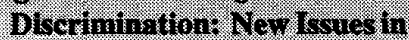
Migraton EdTed by Howard. Adelnan ( 1995 ) 322.05

Arigan refagees Development th and Tepatirition Edited by Howard Adelwon and John Sorrencon (1994) 583990

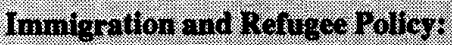

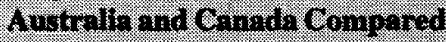

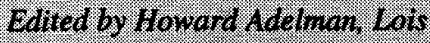
Foster Allon Borow wh and Weyer Burstein (1994)

Volume Ouet Conter, Polloy and Implementation: $\$ 24.95$

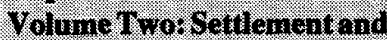
thomact $\$ 24.95$

Brealing Crownt, The 1956

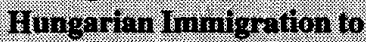
Cunda Wdicd by robert th. Reysertingk (1993) $\$ 6.99$

Taking Retuger Uno Budahist h Noritidimerica

Penny Von Estentk (1992)! 812.98

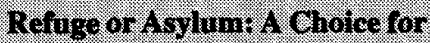
Camida Edired by Howard Adelman and C. Michael Lamphier (1901)

$\$ 18.95$

Romger Rolloy Camon ma be

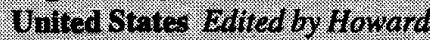
Adelmon (199) 520.95

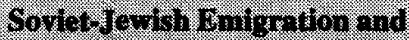
Resentenent in the 1090s. Edived by Tarya Basol and Roberti Brym (1991) 84.98

\section{THPORT:}

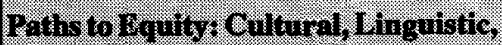

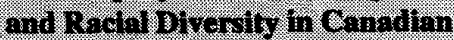

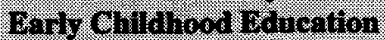

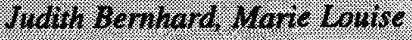
Lefebure et al (1995) 918.95

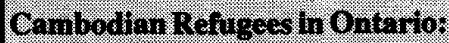
An Bvaluation or Resethemant and Adaptation

Janet VILL Llan (1095)

$\$ 12.95$

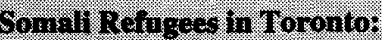

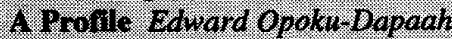
$(1809)$

$\$ 12.95$

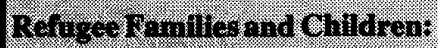

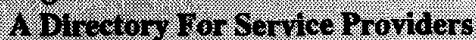
In Metro Toronta John Mothis and

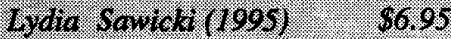

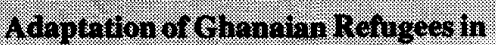
Toronto Edward Opoki-Daparh (19993) 812.50

Report on the Worktiop for Arican community croups in Toromio EdWart Opokn-Daparh (1992) 312.80

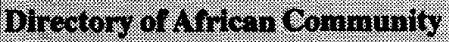
Groum In Toronto EdWard Opoku. Dorowin (163) J12.50

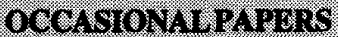

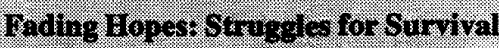

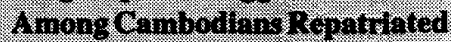
rom Tha Rehryec Camps

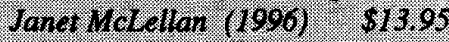

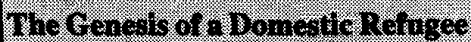
Regine The Caso on THugery

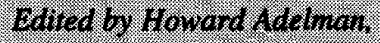

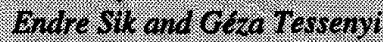
(100\%) 514.95

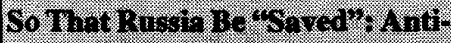

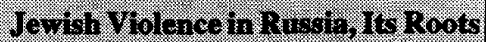
ard Consegurences

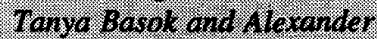

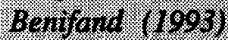

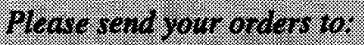

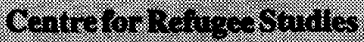

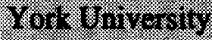

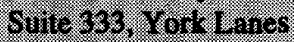

4703.42 .210 .51

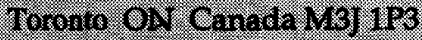

Refuge, Vol. 18,No.4 (November 1999) 